\title{
PERENCANAAN ANGKUTAN PENGUMPAN LRT DAN TRANS JABODETABEK DI BEKASI
}

\author{
Budiharso Hidayat, ATD, MT \\ Dosen STTD \\ Jl. Raya Setu No. 89, Bekasi \\ Telp./Fax : (021) 8254640 \\ Drs. Eko Sudriyanto, MM \\ Dosen STTD \\ Jl. Raya Setu No. 89, Bekasi \\ Telp./Fax : (021) 8254640
}

\author{
Widorisnomo, SH, MT \\ Dosen STTD \\ Jl. Raya Setu No. 89, Bekasi \\ Telp./Fax : (021) 8254640 \\ Dani Hardianto, M.Sc \\ Dosen STTD \\ J1. Raya Setu No. 89, Bekasi \\ Telp./Fax : (021) 8254640
}

\begin{abstract}
The Jabodetabek Transportation Management Agency (BPTJ) in 2018 has plans to develop public transport services that connect residential areas around Jakarta to Jakarta. Public transportation planned to serve settlements in the Jakarta buffer zone is called Jabodetabek Residence Connexion or JR Connexion. This concept is the development of Trans Jakarta mass transportation services as the main route integrated with Trans Jabodetabek transportation. Other small transport services as feeders for Trans Jabodetabek are not yet available and are even well integrated and have not described door to door services. The target of the development of LRT and Trans Jabodetabek Train Feeder transports can reduce congestion in Jakarta with private vehicle users turning to public transportation.
\end{abstract}

Keywords: Congestion, Transport Planning, LRT

\begin{abstract}
Absraksi
Badan Pengelola Transportasi Jabodetabek (BPTJ) pada tahun 2018 mempunyai rencana mengembangkan pelayanan angkutan umum yang menghubungkan kawasan pemukiman sekitar Jakarta menuju Jakarta. Angkutan umum yang direncanakan melayani permukiman di daerah penyangga Jakarta ini disebut Jabodetabek Residence Connexion atau $J R$ Connexion. Konsep ini merupakan pengembangan pelayanan angkutan massal Trans Jakarta sebagai trayek utama yang terintegrasi dengan angkutan Trans Jabodetabek.
\end{abstract}


Pelayanan angkutan kecil lainnya sebagai feeder bagi Trans Jabodetabek belum tersedia bahkan terintegrasi dengan baik serta belum menggambarkan pelayanan dari pintu ke pintu (door to door services). Sasaran dari pengembangan angkutan Feeder Kereta LRT dan Trans Jabodetabek dapat mengurangi kemacetan di Jakarta dengan pengguna kendaraan pribadi beralih ke angkutan umum.

Kata Kunci : Kemacetan, Perencanaan Angkutan, LRT

\section{PENDAHULUAN}

\section{A. LATAR BELAKANG PENELITIAN}

Badan Pengelola Transportasi Jabodetabek (BPTJ) pada tahun 2018 mempunyai rencana mengembangkan pelayanan angkutan umum yang menghubungkan kawasan pemukiman sekitar Jakarta menuju Jakarta. Angkutan umum yang direncanakan melayani permukiman di daerah penyangga Jakarta ini disebut Jabodetabek Residence Connexion atau JR Connexion. (Sumber: https://metro.tempo.co/read/844250/bptj-akan-luncurkan-bus-permukimanjabodetabek-ini-rutenya)

Konsep ini merupakan pengembangan pelayanan angkutan massal Trans Jakarta sebagai trayek utama yang terintegrasi dengan angkutan Trans Jabodetabek. Pelayanan angkutan kecil lainnya sebagai feeder bagi Trans Jabodetabek belum tersedia bahkan terintegrasi dengan baik serta belum menggambarkan pelayanan dari pintu ke pintu (door to door services).

Sasaran dari pengembangan angkutan Feeder Kereta LRT dan Trans Jabodetabek dapat mengurangi kemacetan di Jakarta dengan pengguna kendaraan pribadi beralih ke angkutan umum. 


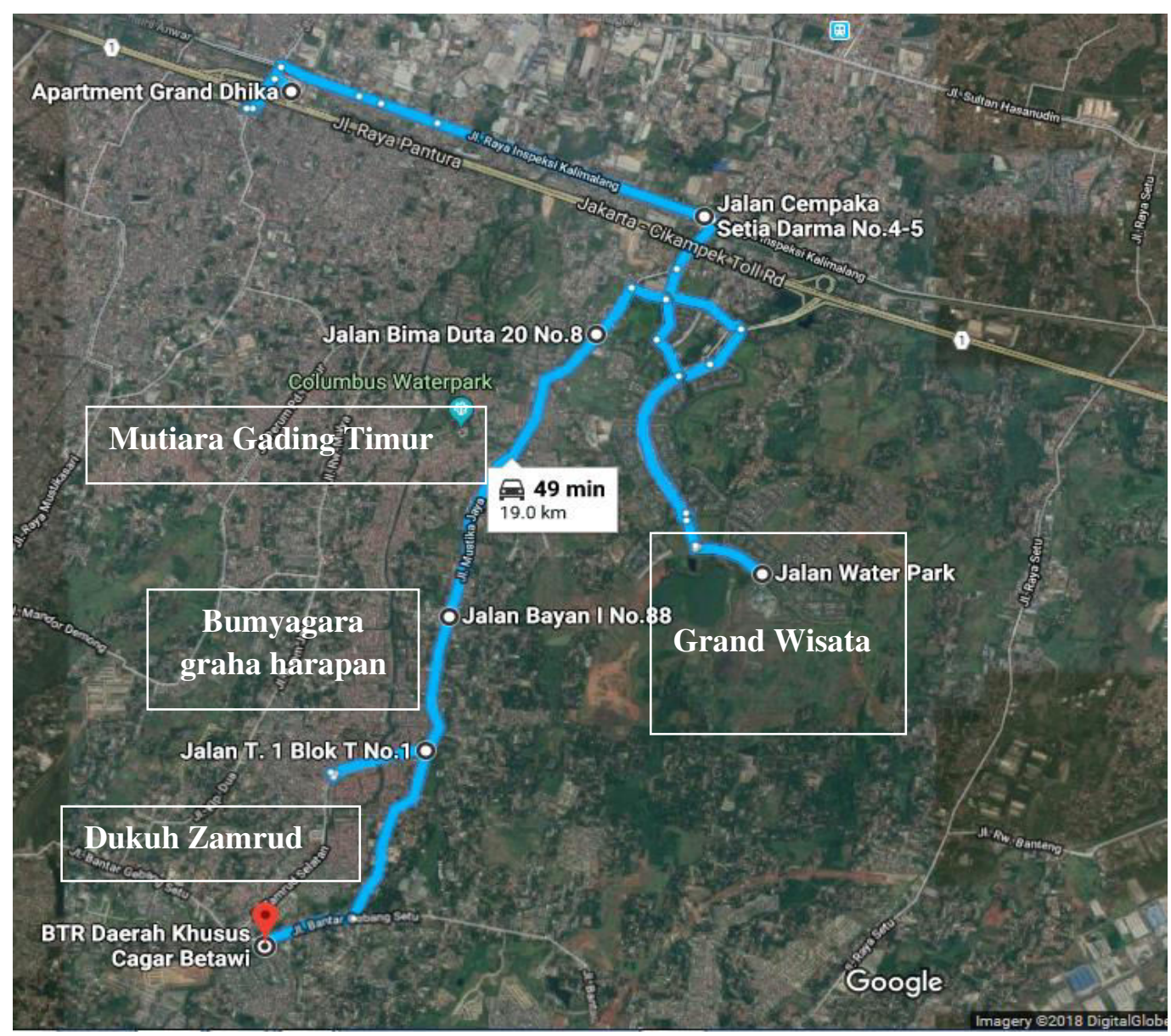

Gambar 1.1 Rencana rute feeder Kereta LRT dan Trans Jabodetabek

Pemilihan lokasi rute dari kawasan pemukiman Mustika Jaya Bekasi menuju Stasiun LRT Bekasi Timur karena sepanjang jalan terdapat berbagai jenis perumahan yang menjadi potensi permintaan pengguna angkutan feeder. Kawasan pemukiman merupakan titik awal perjalanan dan Stasiun LRT Bekasi Timur sebagai lokasi akhir pelayanan yang diintegrasikan dengan layanan LRT atau Trans Jabodetabek.

\section{B. RUMUSAN MASALAH}

Berdasarkan latar belakang yang telah dijelaskan bahwa dapat disimpulkan beberapa permasalahan, diantaranya: 
1. Perkembangan kota meningkatkan permintaan pelayanan angkutan umum yang berdampak terhadap penurunan kualitas pelayanan angkutan umum;

2. Rencana pengembangan angkutan pengumpan dari kawasan pemukiman sekitar daerah penyangga menuju Jakarta;

3. Konsep pelayanan angkutan umum door to door services belum terintegrasi dengan angkutan Trans Jabodetabek serta Trans Jakarta;

4. Kemacetan yang terjadi salah satu penyebabnya adalah penggunaan angkutan pribadi yang tinggi karena pelayanan angkutan umum belum memadai.

\section{MAKSUD DAN TUJUAN PENELITIAN}

Maksud dari pengajuan usulan penelitian Perencanaan Rute Angkutan feeder Kawasan Pemukiman Sekitar Mustika Jaya - Stasiun LRT Bekasi Timur di Bekasi agar tercipta pelayanan angkutan umum yang berkualitas dan terintegrasi sesuai dengan harapan pengguna jasa.

Penelitian ini bertujuan:

1. Mengindentifikasi karakteristik pelaku perjalanan dengan angkutan umum dari Kawasan Pemukiman menuju Jakarta pada saat ini;

2. Mengindentifikasi permasalahan pelayanan angkutan umum dari Kawasan Pemukiman menuju Jakarta saat ini;

3. Menghitung potensi permintaan angkutan umum dari Kawasan Pemukiman menuju Jakarta;

4. Merencanakan rute angkutan umum pengumpan dari Kawasan Pemukiman menuju Jakarta;

5. Menentukan kebutuhan atau fasilitas untuk pelayanan operasional angkutan pengumpan.

\section{METODOLOGI PENELITIAN}

\section{A. METODE ANALISIS}

Adapun analisis yang digunakan dalam penelitian ini adalah : 
1. Analisis Permintaan Angkutan Umum

2. Penentuan Trayek/Rute

3. Penentuan kebutuhan fasilitas angkutan umum (halte)

4. Pemilihan Moda

5. Rencana Operasional

6. Panjang Trayek

\section{HASIL PENGUMPULAN DATA}

A. RENCANA TRAYEK ANGKUTAN PENGUMPAN LRT DAN TRANS JABODETABEK

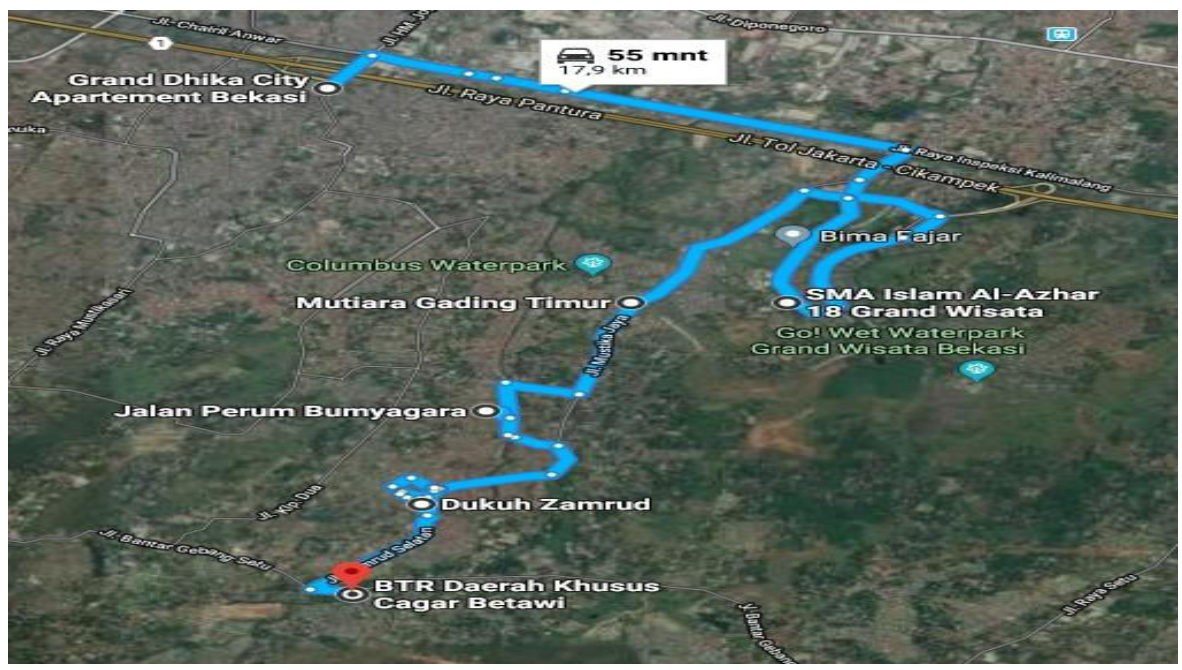

\section{Gambar 4.1 Rencana Jaringan Trayek Angkutan Pengumpan}

\section{B. INVENTARISASI LOKASI PENELITIAN}

Data berkaitan dengan lokasi pemukiman atau perumahan yang yang menjadi sasaran calon pengguna angkutan umum yang direncanakan.Lokasi yang sesuai dengan keperluan penelitian dipilih yang lebih dekat akses ke Ruas Jalan Raya Mustika Jaya, karena itu tidak semua lokasi perumahan dijadikan objek lokasi penelitian. Objek penelitian yang dibutuhkan dalam penelitian ini memiliki kriteria antara lain : 
1. Lokasi perumahan memiliki akses menuju Ruas Jalan Raya Mustika Jaya yang dekat disesuaikan dengan klasifikasi layanan angkutan umum yang direncanakan;

2. Luas lahan yang disediakan untuk minimal 500 unit rumah;

3. Memungkinkan untuk disediakan fasilitas angkutan umum;

4. Karakteristik tata guna lahan campuran;

Survai inventarisasi perumahan dilakukan untuk mengetahui jenis guna lahan sekitar lokasi, posisi terhadap jaringan jalan dan fasilitas yang disediakan.

Adapun perumahan yang dijadikan lokasi penelitian adalah :

1. Perumahan Bekasi Timur Regency

2. Perumahan Dukuh Zamrud

3. Perumahan Bumyagara dan Graha Harapan

4. Perumahan Mutiara Gading Timur

5. Perumahan Grand Wisata

\title{
C. RENCANA OPERASI
}

\section{a. Penentuan Rute}

Usulan rute pelayanan angkutan pengumpan terdiri dari 3(tiga) alternatif yaitu :

\author{
Alternatif 1 \\ Rute 1 : Perumahan BTR - Stasiun LRT - PP \\ Rute 2 : Perumahan Dukuh Zamrud - Simpang Perumahan Bumyagara - \\ Simpang Perumahan Mutiara Gading Timur - Stasiun LRT - PP \\ Rute 3 : Perumahan Grand Wisata - Stasiun LRT - PP
}

\section{Alternatif 2}

Rute 1 : Perumahan BTR - Simpang Perumahan Dukuh Zamrud - Simpang Perumahan Bumyagara - Stasiun LRT - PP 
Rute 2 : Perumahan Mutiara Gading Timur -Perumahan Grand Wisata Stasiun LRT - PP

\begin{abstract}
Alternatif 3
Rute 1 : Perumahan BTR - Simpang Perumahan Dukuh Zamrud - Simpang Perumahan Bumyagara - Simpang Perumahan Mutiara Gading Timur - Perumahan Grand Wisata - Stasiun LRT - PP
\end{abstract}

\title{
b. Jenis dan Type Kendaraan
}

Jenis dan type kendaraan yang digunakan untuk melayani angkutan umum feeder menuju Stasiun LRT Bekasi Timur adalah jenis Bis Sedang dengan kapasitas 19 tempat duduk. Pemilihan moda ini menyesuaikan dengan kondisi jaringan jalan yang dilewati sebagian ruas jalan memiliki lebar sekitar 6 meter untuk ruas jalan Mustika Jaya dan sebagian ruas Jalan Raya Inspeksi Kalimalang sekitar 8 meter termasuk bahu jalan. Ruas jalan Raya Kalimalang ini dapat diopersikan kendaraan dengan dimensi yang lebih besar.

\section{Gambar 4.2. Jenis dan Type Kendaraan yang digunakan}

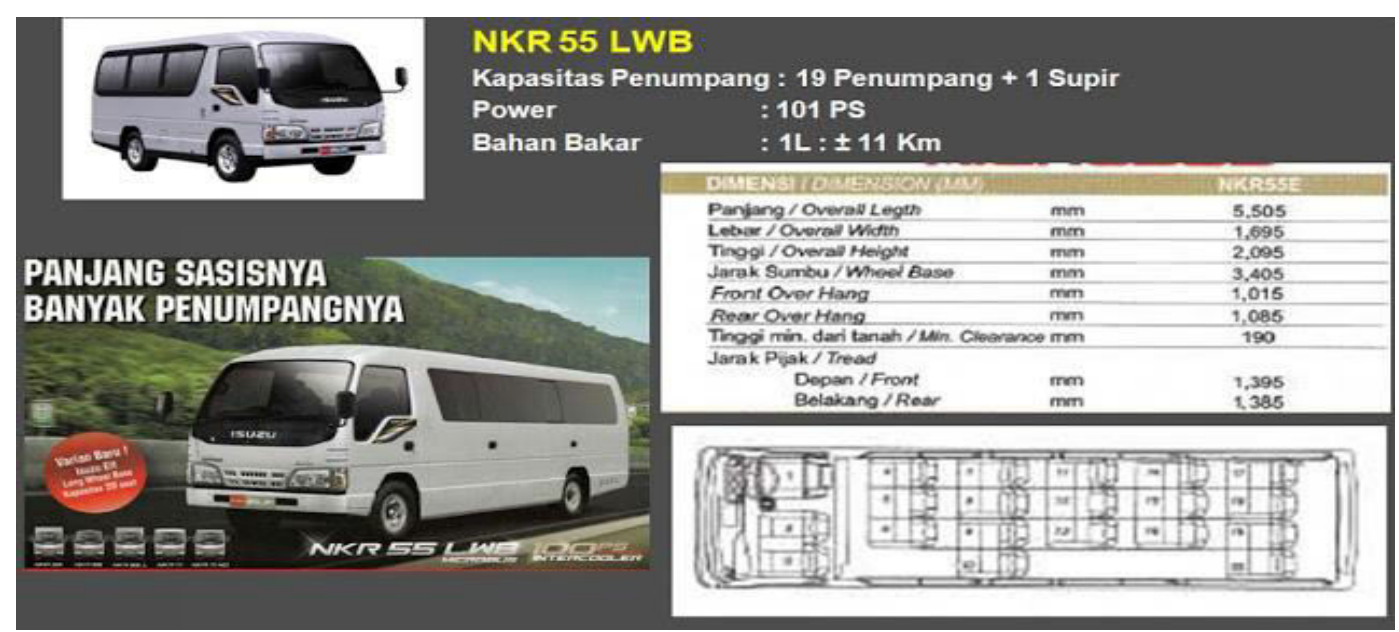




\section{c. Penjadwalan}

Jadwal Operasi Bis Rute 1 (Perum BTR - Stasiun LRT)

\begin{tabular}{rrrr}
\hline \multicolumn{1}{c}{ Rute 1 } & \multicolumn{2}{c}{ Bis 1 } \\
\hline \multicolumn{1}{c}{ Perum BTR } & $\begin{array}{c}\text { Stasiun } \\
\text { LRT }\end{array}$ & $\begin{array}{c}\text { Stasiun } \\
\text { LRT }\end{array}$ & \multicolumn{2}{l}{ Perum BTR } \\
\hline $5: 03$ & $5: 51$ & $5: 54$ & $6: 42$ \\
\hline $6: 45$ & $7: 33$ & $7: 36$ & $10: 06$ \\
\hline $8: 27$ & $9: 15$ & $9: 18$ & $11: 48$ \\
\hline $10: 09$ & $10: 57$ & $11: 00$ & $13: 30$ \\
\hline $11: 51$ & $12: 39$ & $12: 42$ & $15: 12$ \\
\hline $13: 33$ & $14: 21$ & $14: 24$ & $16: 54$ \\
\hline $15: 15$ & $16: 03$ & $16: 06$ & $18: 36$ \\
\hline $16: 57$ & $17: 45$ & $17: 48$ & $20: 18$ \\
\hline $18: 39$ & $19: 27$ & $19: 30$ &
\end{tabular}

Sumber : Hasil analisis, 2018

Jadwal Operasi Bis Rute 2

(Perum Dukuh Zamrud - Stasiun LRT)

\begin{tabular}{rrrr}
\hline \multicolumn{1}{c}{ Rute 2 } & \multicolumn{2}{c}{ Bis 1 } \\
\hline $\begin{array}{c}\text { Perum Dukuh } \\
\text { Zamrud }\end{array}$ & $\begin{array}{c}\text { Stasiun } \\
\text { LRT }\end{array}$ & $\begin{array}{c}\text { Stasiun } \\
\text { LRT }\end{array}$ & $\begin{array}{c}\text { Perum Dukuh } \\
\text { Zamrud }\end{array}$ \\
\hline $5: 02$ & $5: 40$ & $5: 42$ & $6: 20$ \\
\hline $6: 22$ & $7: 00$ & $7: 02$ & $7: 40$ \\
\hline $7: 42$ & $8: 20$ & $8: 22$ & $10: 20$ \\
\hline $9: 02$ & $9: 40$ & $9: 42$ & $11: 40$ \\
\hline $10: 22$ & $11: 00$ & $11: 02$ & $13: 00$ \\
\hline $11: 42$ & $12: 20$ & $12: 22$ & $14: 20$ \\
\hline $13: 02$ & $13: 40$ & $13: 42$ & $15: 40$ \\
\hline $14: 22$ & $15: 00$ & $15: 02$ & $17: 00$ \\
\hline $15: 42$ & $16: 20$ & $16: 22$ & $18: 20$ \\
\hline $17: 02$ & $17: 40$ & $17: 42$ & $19: 40$ \\
\hline $18: 22$ & $19: 00$ & $19: 02$ & $21: 00$ \\
\hline $19: 42$ & $20: 20$ & $20: 22$ &
\end{tabular}

Sumber : Hasil analisis, 2018 
Jadwal Operasi Bis Rute 3

(Perum Grand Wisata - Stasiun LRT)

\begin{tabular}{c|c|c|c}
\hline Rute 3 & Perum Grand \\
Wisata & $\begin{array}{c}\text { Stasiun } \\
\text { LRT }\end{array}$ & $\begin{array}{c}\text { Stasiun } \\
\text { LRT }\end{array}$ & $\begin{array}{c}\text { Perum Grand } \\
\text { Wisata }\end{array}$ \\
\hline $5: 02$ & $5: 29$ & $5: 31$ & $5: 58$ \\
\hline $6: 00$ & $6: 27$ & $6: 29$ & $6: 56$ \\
\hline $6: 58$ & $7: 25$ & $7: 27$ & $7: 54$ \\
\hline $7: 56$ & $8: 23$ & $8: 25$ & $8: 52$ \\
\hline $8: 54$ & $9: 21$ & $9: 23$ & $9: 50$ \\
\hline $9: 52$ & $10: 19$ & $10: 21$ & $10: 48$ \\
\hline $10: 50$ & $11: 17$ & $11: 19$ & $11: 46$ \\
\hline $11: 48$ & $12: 15$ & $12: 17$ & $12: 44$ \\
\hline $12: 46$ & $13: 13$ & $13: 15$ & $13: 42$ \\
\hline $13: 44$ & $14: 11$ & $14: 13$ & $14: 40$ \\
\hline $14: 42$ & $15: 09$ & $15: 11$ & $15: 38$ \\
\hline $15: 40$ & $16: 07$ & $16: 09$ & $16: 36$ \\
\hline $16: 38$ & $17: 05$ & $17: 07$ & $17: 34$ \\
\hline $17: 36$ & $18: 03$ & $18: 05$ & $18: 32$ \\
\hline $18: 34$ & $19: 01$ & $19: 03$ & $19: 30$ \\
\hline $19: 32$ & $19: 59$ & $20: 01$ & $20: 28$ \\
\hline $20: 30$ & $20: 57$ & $20: 59$ & $21: 26$ \\
\hline
\end{tabular}

Sumber : Hasil analisis, 2018

\section{A. KESIMPULAN}

1. Objek penelitian yang dibutuhkan dalam penelitian ini memiliki kriteria antara lain :

a. Lokasi perumahan memiliki akses menuju Ruas Jalan Raya Mustika Jaya yang dekat disesuaikan dengan klasifikasi layanan angkutan umum yang direncanakan;

b. Luas lahan yang disediakan untuk minimal 500 unit rumah;

c. Memungkinkan untuk disediakan fasilitas angkutan umum;

d. Karakteristik tata guna lahan campuran;

2. proporsi tujuan perjalanan dari kawasan/lokasi penelitian adalah :

a. Bekasi dan sekitarnya $65 \%$ (163 responden) 
b. Jakarta Timur sebesar $18 \%$ (45 responden)

c. Jakarta Selatan sebesar $9 \%$ (23 responden)

d. Jakarta Utara sebesar $2 \%$ (5 responden)

e. Jakarta Pusat sebsar $18 \%$ (45 Responden)

3. Proporsi penggunaan moda oleh pelaku perjalanan yaitu :

a. Sepeda motor sebesar 38\% (95 responden),

b. Mobil Penumpang (pribadi) sebesar 21\% (53 responden),

c. Kereta api sebesar $8 \%$ (20 responden),

d. Ojeg sebesar $2 \%$ (5 responden),

e. Sepeda $5 \%$ (13 responden),

f. Angkutan kota sebesar 15\% (38 responden), dan

g. Bus sebesar $11 \%$ (28 responden).

4. Potensi perjalanan dari perumahan sepanjang ruas Jalan Raya Mustika Jaya mencapai 134.632 trip/hari dengan pelaku perjalanan menggunakan angkutan umum sebesar 48.468 trip/hari.Perjalanan dengan menggunakan angkutan umum menuju Bekasi dan sekitarnya mencapai $65 \%$ dari seluruh perjalanan dengan angkutan umum, $35 \%$ perjalanan dengan angkutan umum mengarah ke Jakarta yang diasumsikan akan menggunakan angkutan Trans Jabodetabek atau LRT jika nanti beroperasi.

5. Angkutan umum merupakan sarana atau kendaraan yang disediakan untuk melakukan perjalanan bagi setiap masyarakat yang mana harus efisien dan efektif. Preferensi dari responden mengatakan bahwa :

a. pelayanan angkutan umum sangat memuaskan $1 \%$ (3 responden),

b. pelayanan angkutan umum memuaskan $8 \%$ (18 responden),

c. pelayanan yang diberikan oleh angkutan umum sedang $40 \%$ (88 responden),

d. pelayanan angkutan umum tidak memuaskan sebesar 42\% (111 Responden).

6. Permintaan angkutan umum dari setiap perumahan adalah sebagai berikut :
a. Perumahan Bekasi Timur Regency : 4.637 penumpang/hari 

b. Perumahan Dukuh Zamrud
: 2.896 penumpang/hari
c. Perumahan Bumyagara Graha Harapan: 2.609 penumpang/hari
d. Perumahan Mutiara Gading Timur : 1.624 penumpang/hari
e. Perumahan Grand Wisata $\quad$ : 8.109 penumpang/hari

7. MerencanakanruteangkutanumumdariKawasanPemukimanmenuju Jakarta angkutan umum feeder sebagai berikut :

a. Rute 1 : Perumahan BTR - Stasiun LRT - PP

Panjang rute $12 \mathrm{~km}$, permintaan perjalanan 4.637 penumpang/hari dan kebutuhan armada sebanyak 37 unit.

b. Rute 2 : Perumahan Dukuh Zamrud - Simpang Perumahan Bumyagara - Simpang Perumahan Mutiara Gading Timur - Stasiun LRT - PP

Panjang rute $8 \mathrm{~km}$, permintaan perjalanan 7.129 penumpang/hari dan kebutuhan armada sebanyak 45 unit.

c. Rute 3 : Perumahan Grand Wisata - Stasiun LRT - PP

Panjang rute $5 \mathrm{~km}$, permintaan perjalanan 8.109 penumpang/hari dan kebutuhan armada sebanyak 36 unit.

8. Tarif berdasarkan biaya operasi kendaraan dan keuntungan (10\%) pada posisi factor muat $70 \%$ adalah

a. Rute 1 : tarif yang diusulkan sebesar Rp 15.578,- dibulatkan Rp 16.000,per penumpang sekali jalan.

b. Rute 2 : tarif yang diusulkan sebesar Rp 7.474,- dibulatkan Rp 7.500,per penumpang sekali jalan.

c. Rute 3 : tarif yang diusulkan sebesar Rp 3.341,- dibulatkan Rp 3.500,per penumpang sekali jalan.

\section{B. SARAN}

1. Perlu dilakukan konsolidasi dengan pelayanan lanjutan dan kepastian pelayanan angkutan lanjutan dalam kehandalan waktu pelayanan sesuai jadwal agar angkutan ini terintegrasi dengan baik serta menarik bagi pelaku perjalanan. 
2. Untuk memudahkan dan efisien dalam pelayanan pembayaran dpat dilakukan dengan integrasi sistim tiket terpadu. Model ini memerlukan kajian lebih lanjut.

\section{DAFTAR PUSTAKA}

Hobbs,F.D. 1979, Traffic Planning \& Engineering, 2nd Edition, Pergamon International Library, Oxford

Kanafani, A., 1983, Transportation Demand Analysis, Mc Graw-Hill, New York

Morlok, Edward K., 1984, Pengantar Teknik dan Perencanaan Transportasi, 1984, Penerbit Erlangga, Jakarta.

Nazir, 1988, Metode Penelitian, Ghalia Indonesia, Jakarta

Papacostas, C.S. and Prevedouros, P.D., 1993, Transportation Engineering and Planning Second Edition, Prentice Hall.

Norbert Oppenhein, 1995,Urban Travel Demand Modelling, A Wiley-Interscience Publication, Canada

Thagesen, B., 1996, Highway and Traffic Engineering in Developing Countries, Technical University of Demark, E\&FN

Khisty, C.J. and Lall, B.K., 2005. Dasar - Dasar Rekayasa Transportasi. Jilid 1. Edisi Ketiga. Erlangga. Jakarta.

Sugiyono,2007, Statistik Untuk Penelitian, Edisi kedua belas, Alfabeta, Bandung.

2009, Undang Undang Nomor 22 Tahun 2009 Tentang Lalulintas dan Angkutan Jalan,Jakarta.

...2013, Peraturan Pemerintah Nomor 79 Tahun 2013 Tentang Jaringan Lalu Lintas dan Angkutan Jalan, Jakarta

,2014, Peraturan Pemerintah Nomor 74 Tahun 2014 tentang Angkutan Jalan, Jakarta

2016, Peraturan Menteri Nomor 16 Tahun 2016 dijelaskan bahwa drop zonel pick up point, Jakarta 